\title{
Environmental History of Mangrove Vegetation in Pacific West-Central Mexico during the Last 1300 Years
}

\author{
Blanca L. Figueroa-Rangel ${ }^{1 *}$, Adelina Valle-Martínez ${ }^{2}$, Miguel Olvera-Vargas ${ }^{1}$ and \\ Kam-biu Liu $^{3}$ \\ ' Laboratorio de Paleoecologia y Cambio Climático, Departamento de Ecología y Recursos Naturales, Centro Universitario de \\ la Costa Sur, Universidad de Guadalajara, Jalisco, Mexico, ${ }^{2}$ Programa de Maestría en Ciencias en Manejo de Recursos \\ Naturales, Departamento de Ecología y Recursos Naturales, Centro Universitario de la Costa Sur, Universidad de \\ Guadalajara, Jalisco, Mexico, ${ }^{3}$ Department of Oceanography and Coastal Sciences, College of the Coast and Environment, \\ Louisiana State University, Baton Rouge, LA, USA
}

\section{OPEN ACCESS}

Edited by:

Simon Haberle,

Australian National University, Australia

Reviewed by:

Maarten Blaauw,

Queen's University Belfast, UK

Wenying Jiang,

Institute of Geology and Geophysics, Chinese Academy of Sciences, China

*Correspondence:

Blanca L. Figueroa-Rangel bfrange/@cucsur.udg.mx

Specialty section:

This article was submitted to Paleoecology,

a section of the journal

Frontiers in Ecology and Evolution

Received: 16 June 2016 Accepted: 09 August 2016 Published: 23 August 2016

Citation:

Figueroa-Rangel BL, Valle-Martínez A, Olvera-Vargas M and Liu K-b (2016) Environmental History of Mangrove Vegetation in Pacific West-Central Mexico during the Last 1300 Years. Front. Ecol. Evol. 4:101. doi: 10.3389/fevo.2016.00101
Mangroves are a highly threatened ecosystem due to climate change and human activity, which increases coastal vulnerability. Knowledge about the ecological dynamics of mangroves on a centennial timescale can reveal the different responses in vegetation, which is useful for implementing basic actions for mangrove restoration, conservation and management. A mangrove ecosystem in the Cuyutlán Lagoon area along the Pacific coast of west-central Mexico is significantly altered as a result of industrialization, salt extraction, and road construction. The long-term dynamics of the mangrove ecosystem has also been controlled by Holocene climatic variability. This study reconstructs the environmental history of mangrove vegetation around the Cuyutlán Lagoon during the last $\sim 1300$ years in response to periods of human activity and climate change. The reconstruction was performed using paleoecological techniques in sediment cores that include the use of fossil pollen as a proxy for vegetation and magnetic susceptibility and geochemical data (determined by loss-on-ignition and $\mathrm{X}$-ray fluorescence) as a proxy for past environmental changes. The chronology was determined using ${ }^{14} \mathrm{C}$ dating and the age-depth model was constructed by linear interpolation. Redundancy analysis and non-metric multidimensional scaling (NMDS) were used to discern patterns of distribution of the different proxies. Results revealed that the mangrove pollen assemblage of the Cuyutlán Lagoon was dominated by the arboreal taxa Rhizophora mangle, Euphorbiaceae, Moraceae, and Pinaceae, herbaceous taxa like Poaceae, Chenopodiaceae/Amaranthaceae, and aquatics such as Typhaceae and Cyperaceae. NMDS showed a clear separation between two events of human activity - the Spanish Occupation of Colima ( AD 1523-1524) and the opening of the Manzanillo port ( AD 1824-1825). Climate change events such as the Medieval Climate Anomaly (MCA) ( AD 800-1200) and the Little Ice Age (LIA) ( AD 1350-1850) were also successfully identified. The main responses were mangrove expansion (driven by $R$. mangle) during the LIA and the Manzanillo Port Opening, while the MCA was a highly perturbed period marked by multiple hurricane events and low or no pollen deposition in the sediment. During the Spanish Occupation, the aquatic taxa Typhaceae expanded together with an increase in $\mathrm{Ca}, \mathrm{Sr}$ and carbonate contents.

Keywords: human activity, Holocene, Little Ice Age, medieval climate anomaly, Spanish occupation, tsunamis 


\section{INTRODUCTION}

Mangrove forest, as an ecosystem that develops in the transition zone between marine and terrestrial ecosystems, is constantly subject to tidal variations. Due to this harsh environment with constant changes in temperature, water and salt, mangrove vegetation is robust and very adaptable. As a consequence this forest community presents high persistence and response to disturbance (Alongi, 2008).

Despite its importance and specialization, studies around the world report a decrease in the area occupied by mangrove (MEA, 2005; Friess and Webb, 2014). Therefore, understanding the environmental history of mangrove is of utmost importance for the planning and implementation of effective management and conservation strategies. To better understand ecosystem history in the context of environmental change, it is of extreme importance to comprehend the human-climate disturbance interactions over varying scales of time and space. For mangroves in particular, human disturbances can include overexploitation of forest resources by local communities, conversion into largescale development such as agriculture, forestry, salt extraction, urbanization and infrastructure construction, and diversion of freshwater for irrigation (UNEP, 1994). On the other hand, climate change components that affect mangroves include changes in sea-level, hurricanes, storminess, precipitation, temperature, atmospheric $\mathrm{CO}_{2}$ concentration, ocean circulation patterns and health of functionally connected nearby ecosystems (McLeod and Salm, 2006; Gilman et al., 2008).

Mexico has the fourth highest proportion of mangrove cover (Friess and Webb, 2014) and the fifth with the largest total aboveground biomass (Hutchison et al., 2014). In the coastal lagoons of Pacific west-central Mexico, mangroves comprise the dominant vegetation (López-Portillo and Ezcurra, 2002). The Holocene has been an era of increasing environmental changes in Mexico with human impact prevailing for at least 5000 years (Denevan, 1992). Worldwide the current distribution of mangroves is a legacy of the Holocene and their resilience has endured prolonged fluctuations in relative sea-level (Alongi, 2008).

A mangrove ecosystem in the Cuyutlán Lagoon along the Pacific coast of west-central Mexico is significantly altered as a result of industrialization, salt extraction, and infrastructure development (Torres and Quintanilla-Montoya, 2014). Human impacts have drastically changed the morphology and bathymetry of the lagoon. The long-term dynamics of the mangrove ecosystem here is also controlled by Holocene climatic variability in the Pacific center of Mexico (Valle Martínez, 2015), which is influenced by atmospheric and oceanic circulations, the El Niño-Southern Oscillation (ENSO) phenomena, the latitudinal shift of the Intertropical Convergence Zone (ITCZ) and solar variability (Sosa-Nájera et al., 2010; Carrillo-Bastos et al., 2013; Bianchette et al., in press).

This study reconstructs the environmental history of mangrove vegetation around the Cuyutlán Lagoon during the last $\sim 1300$ years. This important period includes pre-Hispanic as well as Colonial and post-Hispanic time intervals of human intervention. The sediment record can also shed light on the climatic anomalies of the Medieval Climatic Anomaly (MCA) and the Little Ice Age (LIA) (Mayewski et al., 2004; Wanner et al., 2008) which are expected to have caused diverse responses in the regional vegetation (Islebe and Sánchez, 2002; Figueroa-Rangel et al., 2012). Key question addressed in this study: Is it possible to identify timing and responses of the mangrove ecosystem of the Mexican Pacific coast to periods of human activity and climate change during the last $\sim 1300$ years?

\section{STUDY AREA}

The Cuyutlán Lagoon is located between $18^{\circ} 51^{\prime}-19^{\circ} 07^{\prime} \mathrm{N}$ and $103^{\circ} 53^{\prime}-104^{\circ} 07^{\prime} \mathrm{W}$ on the Pacific coast in the state of Colima, México (Figure 1). It is a large lagoon with 7200 ha of water surrounded by mangrove vegetation in different states of conservation. It is $37 \mathrm{~km}$ long with variable dimensions in width $(0.5-6 \mathrm{~km})$. It consists of four water bodies or "Vasos" divided by natural and artificial barriers that allow interchange of water and sediments (Torres and Quintanilla-Montoya, 2014): Vaso I- La Laguna Chica, Vaso II-Mediano, Vaso III-Grande and Vaso IV-Estero Palo Verde.

Soils are predominantly regosol from the Quaternary. The climate according to Köppen and modified by García (1987) is warm subtropical with a mean yearly temperature between 22 and $28^{\circ} \mathrm{C}$ and average rainfall between 600 and $1100 \mathrm{~mm}$ (INEGI, 2009).

The mangroves of Cuyutlán Lagoon are represented by three species: Rhizophora mangle, Laguncularia racemosa, and Avicennia germinans, in association with Batis maritima, Distichlis spicata, and Atriplex spp. Deciduous forest and farmland (coconut, corn and sugar cane) are present near the lagoon. Natural vegetation around the Cuyutlán Lagoon has been strongly modified by humans during the last 50 years (Mellink and Riojas-López, 2007; Ruíz-Montero, 2009; Téllez García, 2010).

\section{MATERIALS AND METHODS}

\section{Field and Laboratory Techniques}

A $97 \mathrm{~cm}$ core (S1M1) consisting of gray-brown sandy-organic sediment was retrieved from Vaso IV-Estero Palo Verde, in the Cuyutlán Lagoon, using a modified Russian corer. The core was retrieved in open water at $1.30 \mathrm{~m}$ depth, $30 \mathrm{~m}$ from the shoreline. It was described in the field and wrapped in clingfilm and aluminum foil. Samples were analyzed at $1 \mathrm{~cm}$ intervals throughout the sequence for magnetic susceptibility, loss on ignition and elemental concentration. Magnetic susceptibility (MS) was measured using a Bartington MS2 device in order to determine the presence of iron-bearing minerals within each of the three sedimentary sequences (Thompson and Oldfield, 1986). Bulk density and organic and carbonate contents were determined through loss-on-ignition analysis according to Dean (1974). Elemental concentrations (ppm) of 17 chemical elements were measured using an X-ray fluorescence (XRF) Olympus Innov-X Delta Standard Analyzer RoHS/WEEE DS 6500CC at the Global Change and Coastal Paleoecology Laboratory at Louisiana State University. Organic matter (OM), carbonate 


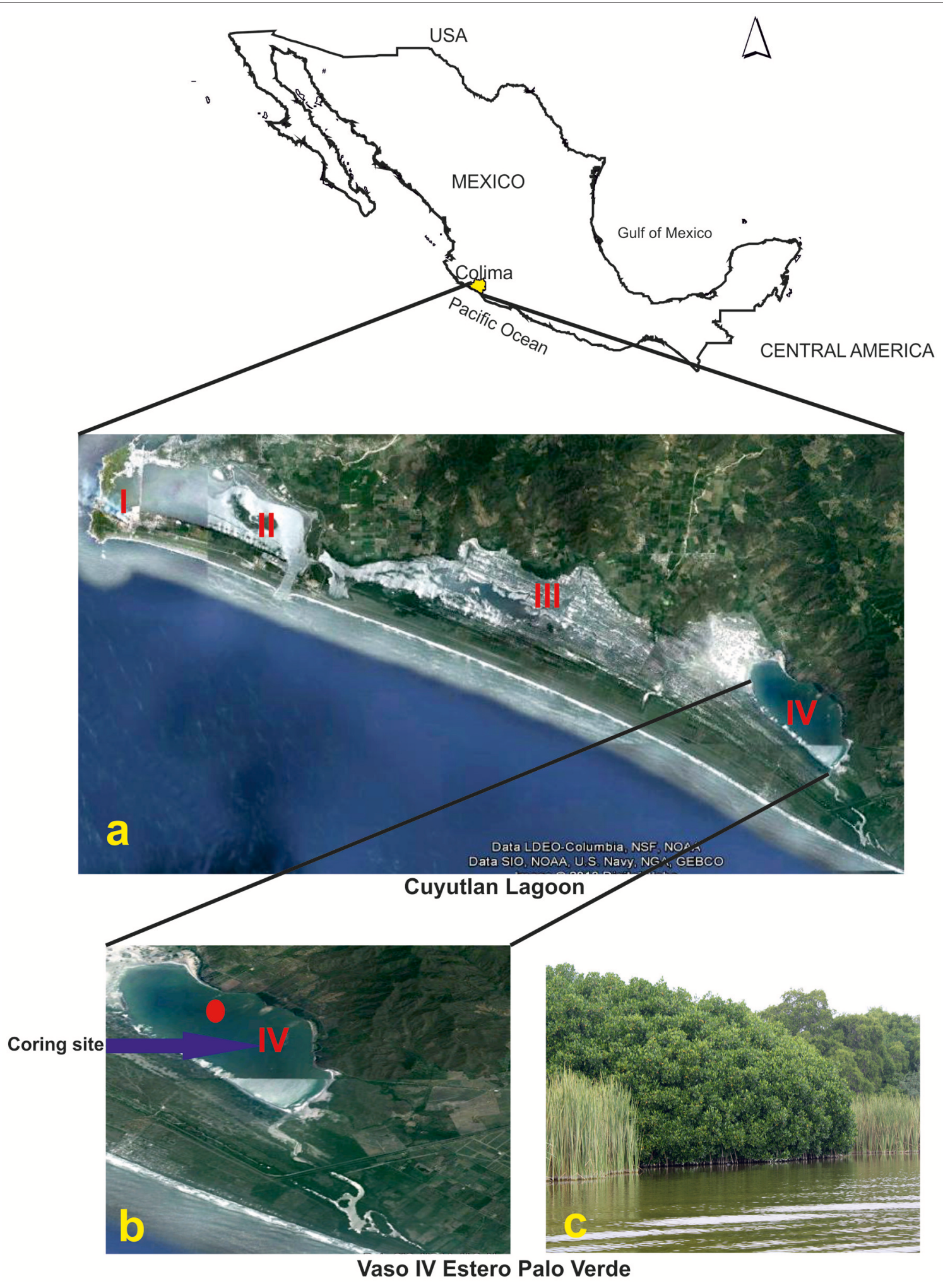

FIGURE 1 | Location of the study area. (A) Cuyutlan Lagoon in the Colima state, Pacific coast of Mexico with "Vaso" I, II, II, and IV; (B) The coring site at "Vaso" IV-Estero Palo Verde; (C) Partial view of Cuyutlan Lagoon and the nearby mangrove forest. 
content (CC), as well as chemical elemental composition, were used as a proxy for extreme natural events such as hurricanes and tsunamis (Liu and Fearn, 2000a,b) but also to detect possible impact of human activities.

We also estimated changes in delivery rates of organic matter (Meyers and Teranes, 2001) by the Mass Accumulation Rate (MAR). MAR was calculated by the product of bulk density and the linear sedimentation rate (LSR) data taken from the age-depth model of each sedimentary sequence.

Subsamples of $0.9 \mathrm{~cm}^{3}$ were used for pollen extraction through the standard acetolysis method (Bennett and Willis, 2001). Sample resolution varies along the sequence; every $1 \mathrm{~cm}$ for the first $14 \mathrm{~cm}$, every $2 \mathrm{~cm}$ from 15 to $56 \mathrm{~cm}$ and every $5 \mathrm{~cm}$ from 57 to $97 \mathrm{~cm}$. Mexican history can be divided into two epochs, the Pre-Hispanic era before the Spanish conquest (before 1519 $\mathrm{AD}$ ) and the Post-Hispanic era (after 1521 AD), after the Spanish conquest. The highest resolution corresponded to the last $\sim 500$ years as the impact of human activities was assumed to be extensive after the Spanish conquest in Mexico.

Pollen counts were converted to percentages and then were plotted in a pollen percentage diagram using PSIMPOLL 4.27 (Bennett, 2009). Pollen percentages were based on a pollen sum excluding fern and fungal spores and pollen and spores from aquatic taxa (Cyperaceae, Nymphaceae, and Typhaceae). A known quantity of exotic Lycopodium spores was added to each sample in order to estimate pollen (pollen grains $/ \mathrm{cm}^{3}$ ) and microscopic charcoal concentrations (charcoal $\mathrm{cm}^{2} / \mathrm{cm}^{3}$ ). Pollen and spores were identified using comprehensive pollen and spore reference collection of the Sian Ka'an Biosphere Reserve, a large area of mangroves in Southeast Mexico (Villanueva-Gutiérrez et al., 1991). Microscopic charcoal concentration (CHAR) was quantified in each level analyzed for pollen using the point count method (Clark, 1988). This was treated as a proxy for fire incidence within the pollen source area (Whitlock and Larsen, 2001).

\section{Data Analysis}

The chronology for the sequence was established from accelerator mass spectrometry (AMS) ${ }^{14} \mathrm{C}$ dates (Beta-Analytic Laboratory, Miami, Florida, USA) of organic material taken from the sedimentary sequence. An age-depth model using linear interpolation was developed using the "Classical age-depth modeling" (CLAM) software (version 2.2) in R (Blaauw, 2010). $95 \%$ confidence intervals were calculated by analysing the distribution of 1000 randomly generated age models (Blaauw, 2010). All radiocarbon ages were calibrated using the INTcal13 calibration curve (Reimer et al., 2013).

Zonation was undertaken by optimal splitting and significant zones were resolved using a broken-stick model (Bennett, 1996, 2009). Rarefaction analysis was applied to provide an estimate of the palynological richness in each sample (Birks and Line, 1992). The analyses were developed in PSIMPOLL 4.27 (Bennett, 2009).

We used Redundancy Analysis (RDA) to assess the contribution of the chemical elements, OM, CC, MS, and MAR in explaining patterns of fossil pollen taxa composition along time. RDA is a form of constrained ordination that examines how much of the variation in one set of variables explains the variation in another set of variables. RDA is particularly appropriate when the gradient length is short and species distributions are assumed to be linear (or generally monotonic; ter Braak, 1986). We computed Non-metric Multidimensional Scaling (NMDS) ordinations; one using a matrix with the chemical elements and another with OM, CC, MS, and MAR to reveal changes in the values of these variables over the past $\sim 1300$ years. All ordinations were computed in CANOCO v.5 (ter Braak and Smilauer, 2012).

\section{RESULTS}

\section{Chronology}

Radiocarbon dating of the core taken from the Cuyutlán Lagoon indicates that sediment accumulation began about 649-717 cal yr AD (Figure 2). The age-depth relationship was modeled using linear interpolation indicating that approximately $1 \mathrm{~cm}$ of sediment accumulated in the basin every 15 years. Confidence intervals were reported using two-sigma range (Table 1).

The present sequence retrieved from the Cuyutlán Lagoon in the west-central region of the Pacific Ocean in the Colima state of Mexico covers two important periods of climate change: the Medieval Climate Anomaly $(\sim \mathrm{AD} 830$ 1100) (PAGES-2k-Consortium, 2013) and the Little Ice Age ( AD 1350-1850) (Grove, 2001). Other events or periods of significant environmental impacts include the tsunamigenerating earthquake of 1932 (Okal and Borrero, 2011), as well as two key periods of human activity in the region: the Spanish Occupation of Colima ( AD 1523-1524) (Sauer, 1948) and the opening of the Manzanillo port ( AD 1824-1825) (Calderón Aragón, 2001; Patiño-Barragán et al., 2009).

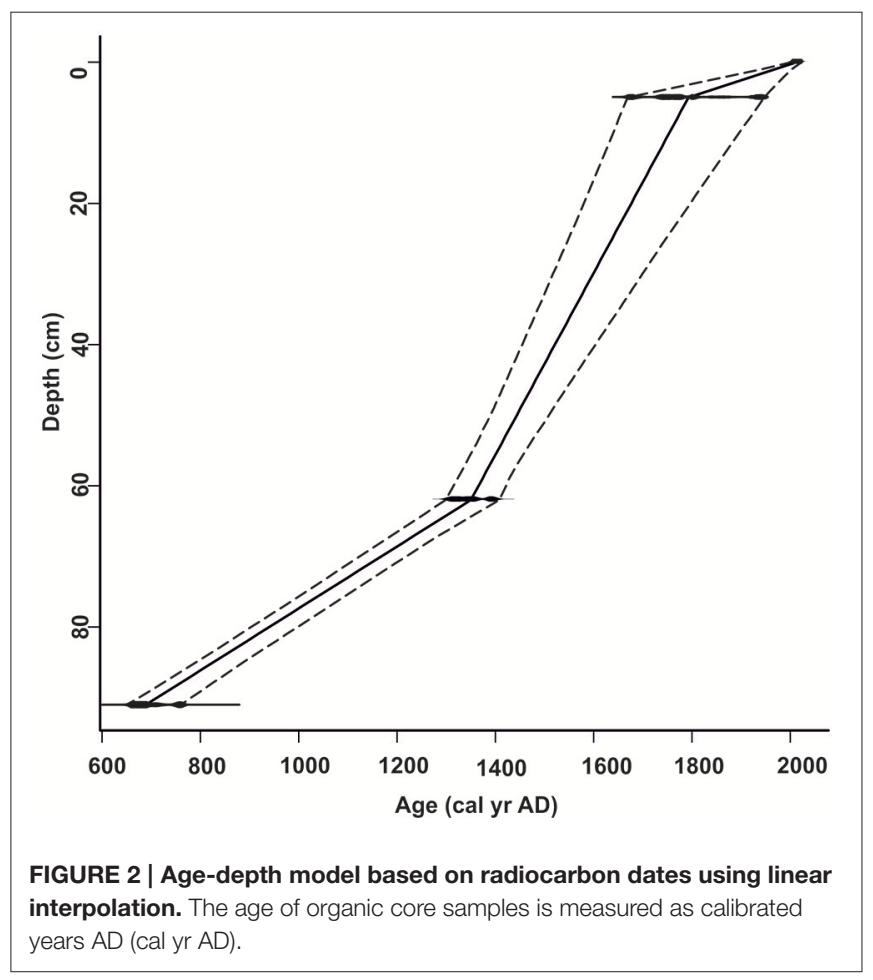


TABLE 1 | Radiocarbon calibrated dates calculated from CLAM v. 2.2 in $R$ computer program (Blaauw, 2010) and the data set INTCAL13 (Reimer et al., 2013) used to develop the chronology for S1M1 core at Cuyutlan Lagoon, west-central, Mexico.

\begin{tabular}{llcc}
\hline Depth $\mathbf{( c m )}$ & $\begin{array}{l}\text { Laboratory } \\
\text { code }\end{array}$ & $\begin{array}{c}\text { Conventional } \\
\text { radiocarbon age }\end{array}$ & $\begin{array}{c}\text { 2-sigma range } \\
\text { (cal. yr AD) }\end{array}$ \\
\hline 5 & Beta -368308 & $170 \pm 30$ & $1724-1815$ \\
62 & Beta -368310 & $600 \pm 30$ & $1298-1372$ \\
91 & Beta -375247 & $1330 \pm 30$ & $649-717$ \\
\hline
\end{tabular}

\section{Mangrove Forest Dynamics and Its Environment}

The mangrove forest pollen assemblage of the Cuyutlán Lagoon showed variant stages of taxa composition from $\sim 1300$ years to present. The optimal splitting method divided the core in six fossil pollen zones. Aquatic (Typhaceae and Cyperaceae), herbaceous (Poaceae, Chenopodiaceae/Amaranthaceae) and arboreal taxa (Rhizophora mangle, Euphorbiaceae, Moraceae, and Pinaceae) dominate the pollen sum (Figure 3).

\section{Zone Z-1 (97-90 cm)}

This zone was dominated by Cyperaceae with relatively high Poaceae and Chenopodiaceae/Amaranthaceae (Cheno/Ama). Among arboreal taxa, Euphorbiaceae, Moraceae, Avicennia germinans, and Rhizophora mangle occurred at high percentages. Palynological richness was relatively low for this zone and CHAR displayed a small peak at the base of the sequence (Figure 3).

High OM and MAR characterized this zone but these curves declined sharply in the upper part, while MS showed opposite trends. The abundance of some chemical elements such as $\mathrm{Fe}$, $\mathrm{Mn}, \mathrm{Cr}, \mathrm{Ti}$, and $\mathrm{Sr}$ was high at the bottom, decreased in the middle, and rose again at the top (Figure 4).

\section{Zone Z-2 (90-70 cm)}

Zone Z-2 was mainly composed of inorganic sediments that were marked by extremely high MS values and minimal OM. MS steadily declined upward, accompanied by increasing, albeit fluctuating, OM. Geochemically this zone was characterized by high concentrations of all terrigenous elements ( $\mathrm{Ti}, \mathrm{Cr}, \mathrm{Mn}, \mathrm{Fe}$ ) as well as Sr, a marine indicator (Woodruff et al., 2015) while Ca contents decreased slightly. Palynologically this zone was marked by the presence of a non-polleniferous layer layer in the middle (Figure 3). Cyperaceae was the dominant $(>80 \%)$ component at the bottom of the zone but became much less frequent $(\sim 30 \%)$ at the top. R. mangle and other arboreal taxa were also present at the bottom as well as some herbs such as Cheno/Ama and Poaceae. Chronologically zone Z-2 spans $\sim$ cal. AD 712-1168, which encompasses most of the MCA ages (Figures 3, 4).

\section{Zone Z-3 $(70-38 \mathrm{~cm})$}

Cheno/Ama pollen reached maximum frequencies in this zone. R. mangle, Euphorbiaceae and Moraceae dominated the arboreal pollen sum but other tree families (Fabaceae, Aracaceae, and Rubiaceae) also appeared during this period. Avicennia germinans and Laguncularia racemosa were also present. Pinaceae increased at the top of the zone together with most of the herbs. Aquatic taxa (Cyperaceae, Nymphaceae, and Typhaceae) were also present. Palynological richness fluctuated in this zone with two of the highest values in the whole sequence. CHAR was also represented with two peaks (Figure 3).

This part of the sequence is characterized by increasing OM, declining MS values, and a moderately constant MAR. The upper half of the zone saw a distinct increase in CC. An opposite array evolved with the chemical elements which values declined in the upper half of the zone (Figure 4).

\section{Zone Z-4 (38-12 cm)}

A remarkable increase in the arboreal pollen of $R$. mangle, Moraceae and Pinaceae occurred in this zone. This was concurrent with the highest peak in Typhaceae and Nymphaceae, concomitant with a decline in Poaceae and Cheno/Ama but high values for Asteraceae. Elevated values were evident for pollen concentration and palynological richness (Figure 3). CC extended its peak from the previous zone reaching a maximum in the lower part of the zone. $\mathrm{Ca}$ and $\mathrm{Sr}$ also followed this trend (Figure 4).

\section{Zone Z-5 (12-4 cm)}

This zone is characterized by the sharp increase in $R$. mangle, together with a decrease in aquatics (Typhaceae, Nymphaceae, and Cyperaceae. Palynological richness dropped during this period (Figure 3).

The values for $\mathrm{OM}$ and $\mathrm{CC}$ were constant in this zone. The chemical elements $\mathrm{Cr}$ and $\mathrm{Mn}$ increased in the upper part of the zone while $\mathrm{Ca}$ and $\mathrm{Sr}$ showed a remarkable decrease (Figure 4).

\section{Zone Z-6 $(4-0 \mathrm{~cm})$}

The optimal splitting method separated these few samples from the rest. Even though there were only four samples, the environmental changes they represented seem to be essential for the understanding of the recent dynamics of the lagoon. Avicennia germinans and Laguncularia racemosa increased in this zone, together with Cyperaceae and Nymphaceae. Palynological richness was low and no CHAR was found (Figure 3).

This period seems to be critical for the environment of the mangrove forest as the highest values in MAR and CC occurred in this zone, coupled with dramatic peaks in $\mathrm{Ca}$ and $\mathrm{Sr}$ and a considerable decrease in MS, Ti, Cr, Mn, and Fe (Figure 4).

\section{The Interaction of Different Proxies}

Results of the NMDS for chemical elements revealed a stress (a measure of the optimality of an ordination solution) of 0.034 . Cumulative explained variation was $59.8 \%$ for axis 1 and $89.2 \%$ for axis 2. The ordination results revealed a clear separation of different groups of samples according to chemical elemental composition. In particular, samples representing the period of the Spanish Occupation of Colima ( AD 1523-1524) and those representing the opening of the Manzanillo port $(\sim \mathrm{AD} 1824$ 1825 ), including possibly the tsunami of 1932 , are distinguishable from each other and from the rest of the core samples on axis 1. Axis 2 also separates the two climate change periods, with the MCA ( AD 800-1200) samples having positive values and 


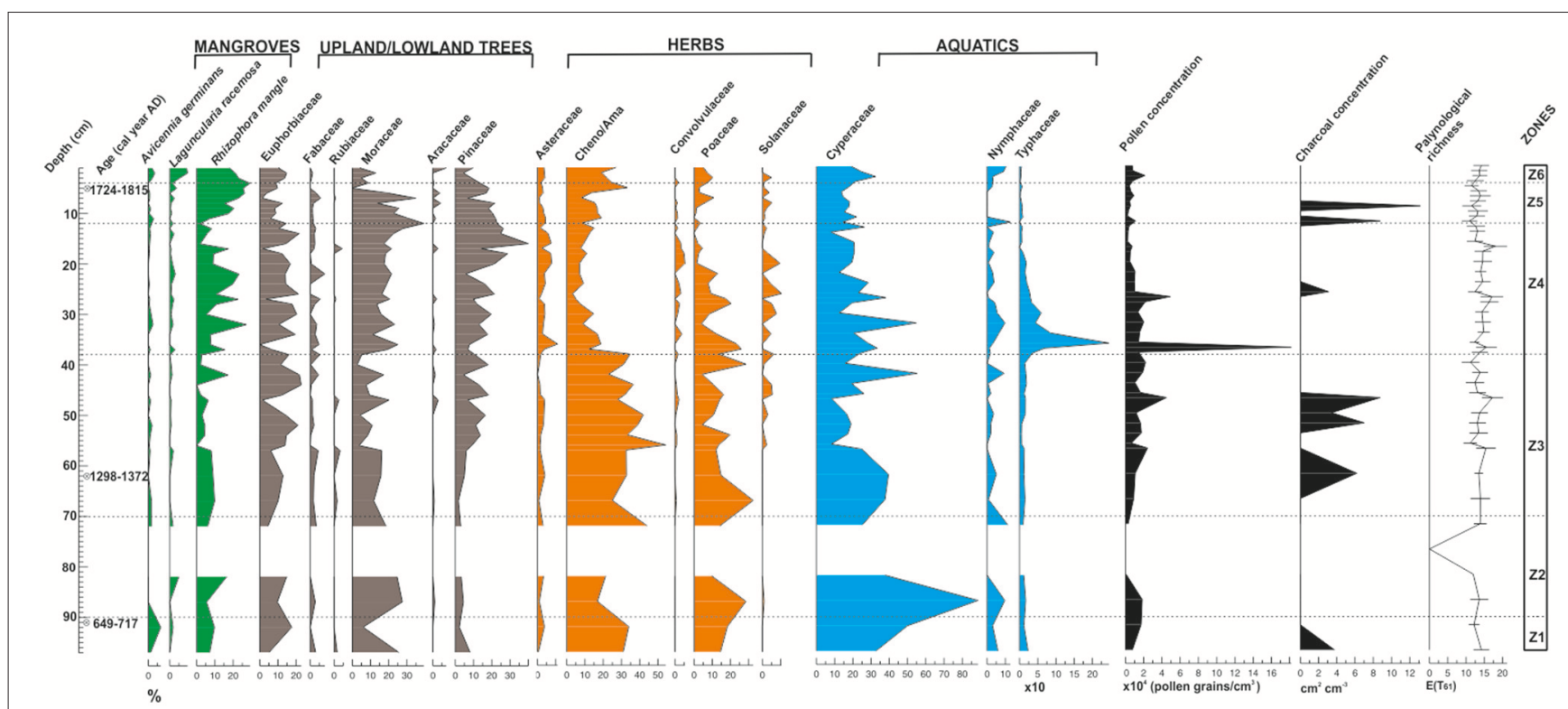

FIGURE 3 | Pollen percentage diagram, pollen concentration, palynological richness and microscopic charcoal concentration for mangrove forest of the Cuyutlan Lagoon in the Pacific coast of Mexico. Divisions are delineated by zones according to the optimal splitting option available in PSIMPOLL

4.27(Bennett, 2009). Dates on the Y-axis are calibrated yr AD.

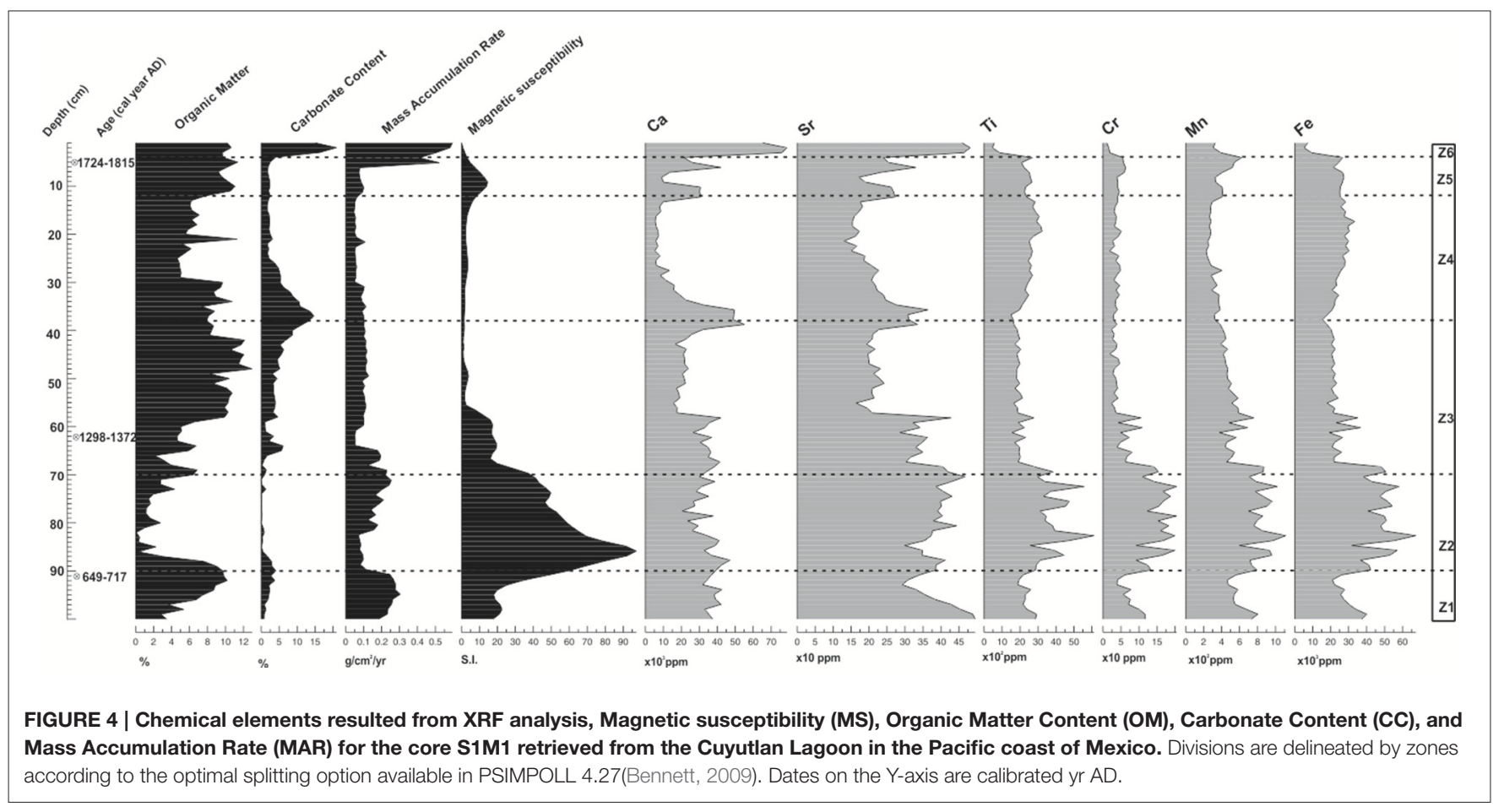

the Little Ice Age ( AD 1350-1850) samples mostly having negative values. On the other hand, samples from the two climate change periods are distinguishable from those of the two human activity periods along axis 2 (Figure $\mathbf{5 A}$ ). Nevertheless, the box and whiskers plots for the chemical elements suggest that only Ti presents extreme values linked to both human and climate change disturbances, with the lowest values related to ages close to the Manzanillo port opening and the high values related to the MCA. Ca showed high values for the Manzanillo port opening. $\mathrm{Cr}$ and $\mathrm{Fe}$ displayed outliers for the MCA (Figure 5B).

NMDS for OM, CC, MS, and MAR revealed a stress of 0.0312 . Cumulative explained variation was $87.6 \%$ for axis 1 and $96.7 \%$ 


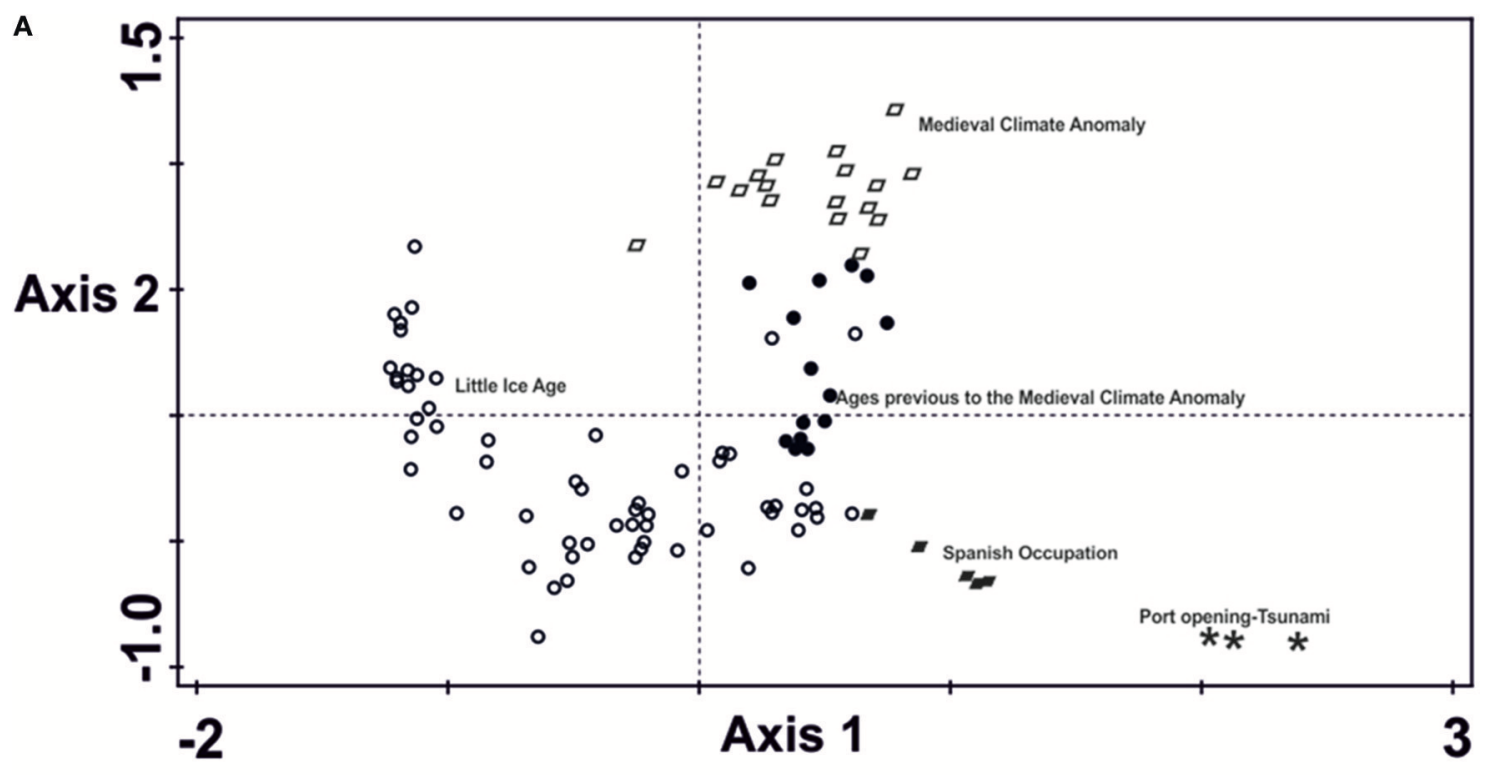

B
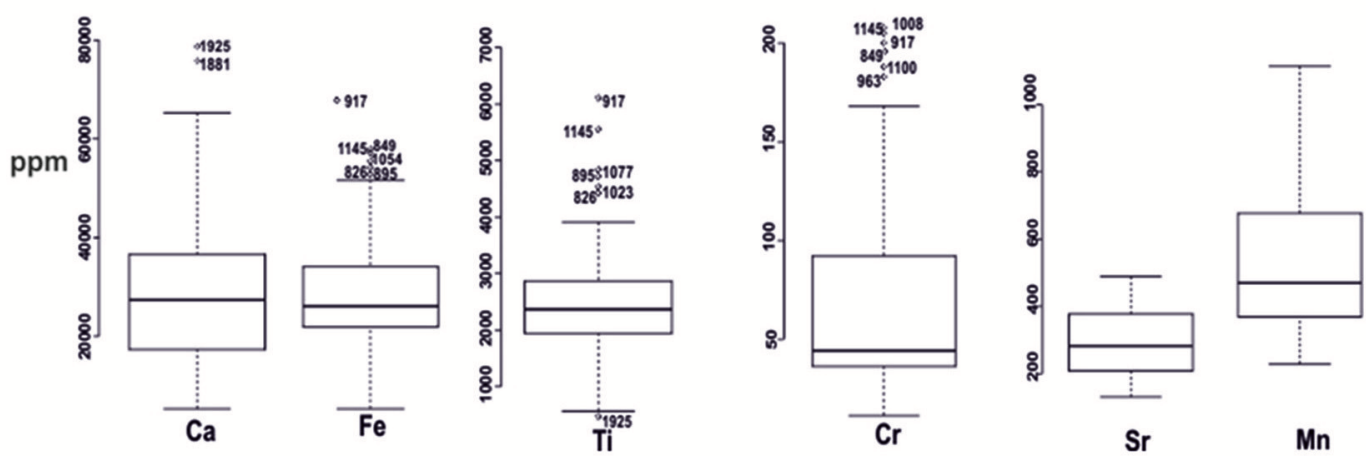

FIGURE 5 | (A) Non-metric multidimensional scaling ordination of chemical element composition by ages. The different symbols represent ordination scores. They represent ages in calibrated years AD. Ages in black open circles correspond with the Little Ice Age; in black circles to ages previous to the MCA; in open black rhomboids to the Medieval Climate Anomaly; in filled black rhomboids to the Spanish Occupation and in asterisks to the Manzanillo port opening and the tsunami of 1932. (B) Box and whiskers plots showing extreme values for the chemical elements.

for axis 2. The ordination results revealed a clear separation of different groups of samples along axis 1 , from the oldest samples at the left of the diagram to the youngest ones at the right. Besides, it also ordered the samples according to periods of human activity and climate change, similar to the chemical elements ordination (Figure 6A).

OM showed no extreme values. CC was the only proxy revealing samples of the Spanish Occupation of Colima as extreme high values. MS extreme high values mostly related to the MCA. MAR and CC displayed high values associated with ages closed to the Manzanillo Port Opening and/or the tsunami of 1932 (Figure 6B).

RDA results developed to assess the contribution of the chemical elements, OM, CC, MS and MAR to explain temporal changes of fossil pollen assemblages showed a strong significant relationship $(p=0.05)$ for $\mathrm{Ca}(t=2.84)$, $\mathrm{Co}(t=-2.20)$, $\mathrm{Sr}$ $(t=-3.00), \mathrm{OM}(t=2.24)$, and CC $(t=-2.63)$ in axis $1\left(\lambda_{1}=\right.$ $0.1109)$. For axis $2\left(\lambda_{2}=0.0822\right)$, they were $\mathrm{Ca}(t=-2.19), \mathrm{Mn}$ $(t=3.17), \operatorname{Ti}(t=-2.10), \mathrm{CC}(t=3.48)$, and MAR $(t=-4.66)$. Cheno/Ama, Typhaceae and Cyperaceae were the taxa closer to the CC vector while $R$. mangle and $L$. racemosa were closer to the $\mathrm{OM}$ vector. $\mathrm{Ca}$ and $\mathrm{CC}$ vectors were also associated with the samples of the Spanish Occupation of Colima, and MAR with the Manzanillo Port Opening and/or the tsunami of 1932 (Figure 7).

\section{DISCUSSION}

\section{Mangrove Vegetation Changes over the Last $\sim 1300$ Years}

The environmental history reconstruction of the Cuyutlán Lagoon during the last $\sim 1300$ years showed a dynamic mangrove community with changes in dominance among the different taxa.

Fossil pollen representing mangrove trees corresponded to three of the four species reported for Mexico (CONABIO, 2009) - R. mangle, L. racemosa and A. germinans in descending 


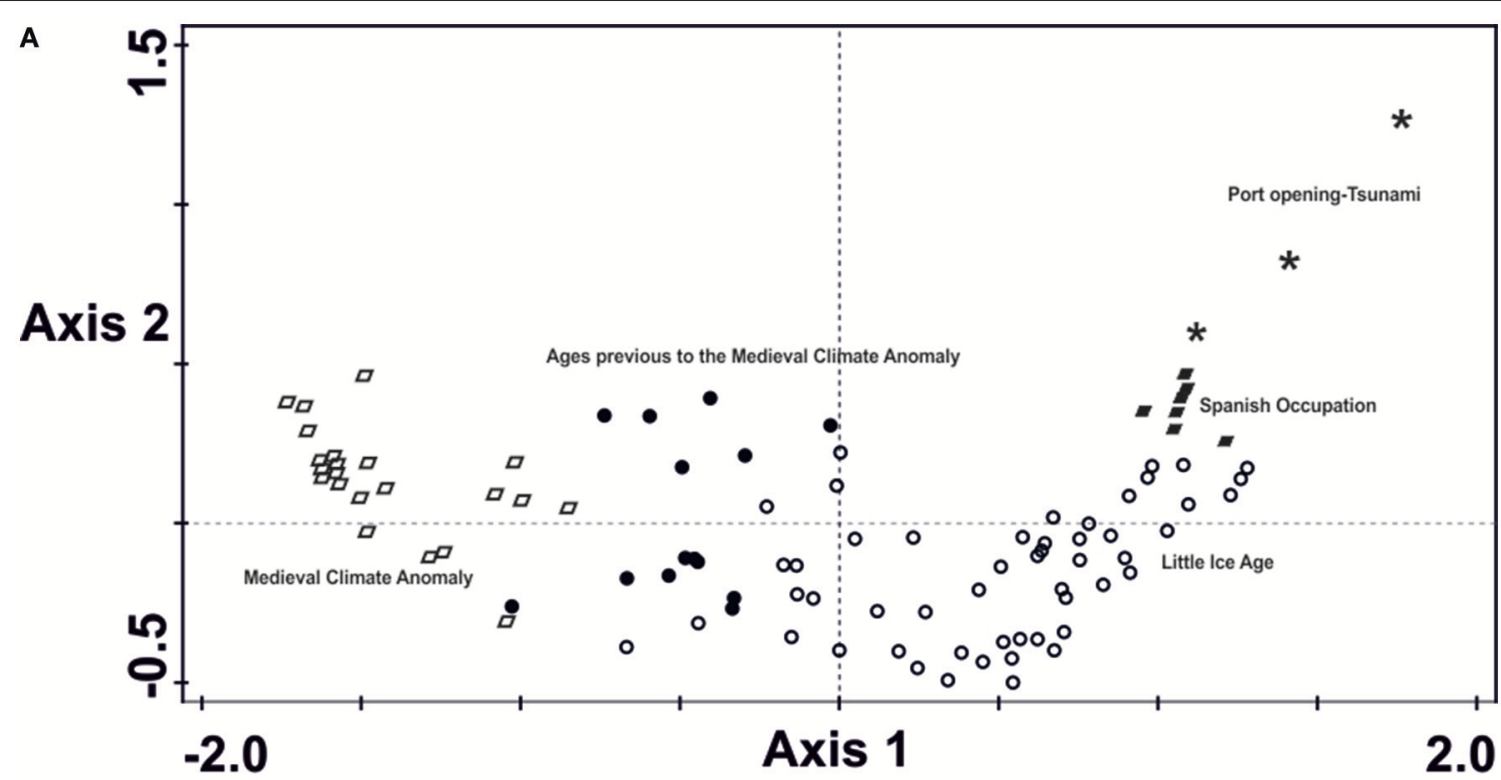

B
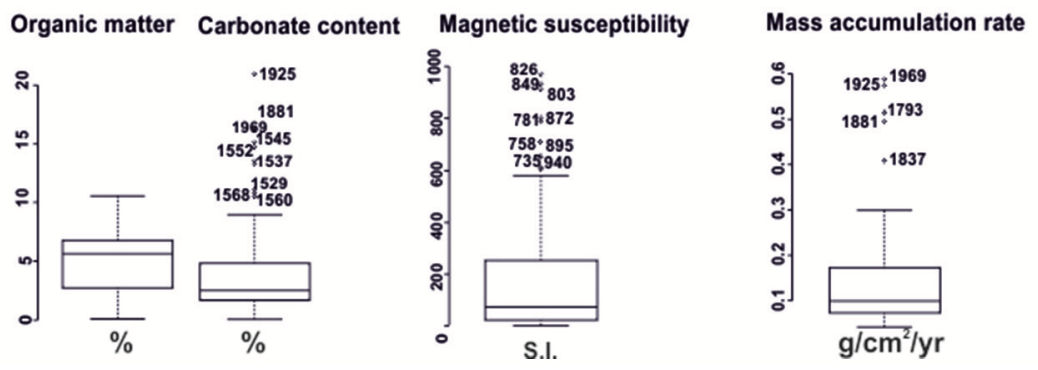

FIGURE 6 | (A) Non-metric multidimensional scaling ordination of Organic matter, Carbonate content, Magnetic susceptibility and Mass Accumulation Rate by ages. The different symbols represent ordination scores. They represent ages in calibrated years AD. Ages in black open circles correspond with the Little Ice Age; in black circles to ages previous to the MCA; in open black rhomboids to the Medieval Climate Anomaly; in filled black rhomboids to the Spanish Occupation and in asterisks to the Manzanillo port opening and the tsunami of 1932. (B) Box and whiskers plots showing extreme values for Organic matter, Carbonate Content, Magnetic susceptibility and Mass Accumulation Rate.

order of percentages. This pattern of dominance agreed with studies on the present-day vegetation undertaken in Vaso IVEstero Palo Verde (Téllez García, 2010) showing R. mangle to be the most abundant mangrove species with over 1367 trees/ha followed by $L$. racemosa with 980 trees/ha. The populations of all three mangrove species increased greatly from $\sim \mathrm{AD} 1815$ to the present, a period concurrent with the Manzanillo Port Opening and the tsunami of 1932. It is possible that rapid deposition of sediments provided sources of elevation (Krauss et al., 2014), creating good conditions for mangrove colonization.

Pollen frequencies of tropical upland forest taxa such as Moraceae and Euphorbiaceae displayed an opposite trend to those of the mangrove species. They were prominent from $\sim \mathrm{AD} 1305$ to 1793 , when the pollen of mangroves were low. Their contraction occurred precisely during the expansion of R. mangle, L. racemosa and A. germinans ( $\sim \mathrm{AD} 1815)$. Moraceae pollen in the study region was probably mainly derived from Brosimum alicastrum and Ficus spp., and Euphorbiaceae includes Hura polyandra and Croton sp. (Padilla-Velarde et al., 2006;
Valle Martínez, 2015). Palynological studies from other coastal regions, such as the Yucatan Peninsula (Islebe and Sánchez, 2002; Torrescano-Valle and Islebe, 2015) and Chiapas (JooChang et al., 2015) in Mexico, Nicaragua (McCloskey and Liu, 2012) in Central America and Florida in USA (Yao et al., 2015), found these same pollen taxa as part of the forest dynamics in mangrove ecosystems, although the abundance of these tropical pollen taxa varied according to the location as a function of local environmental factors.

Herbaceous taxa abundances in the pollen assemblages of the Pacific west-central Mexico were not significantly different from those reported from other mangrove-dominated coastal areas. Poaceae and Cheno/Ama expanded prior to the Spanish Occupation of Colima in AD 1523.

The aquatic components Cyperaceae and Nymphaceae expanded strikingly at the start of the MCA following by a decrease at the end of this period. A second significant increase occurred after the Spanish Occupation of Colima when Typhaceae also rose to its highest peak. These taxa 


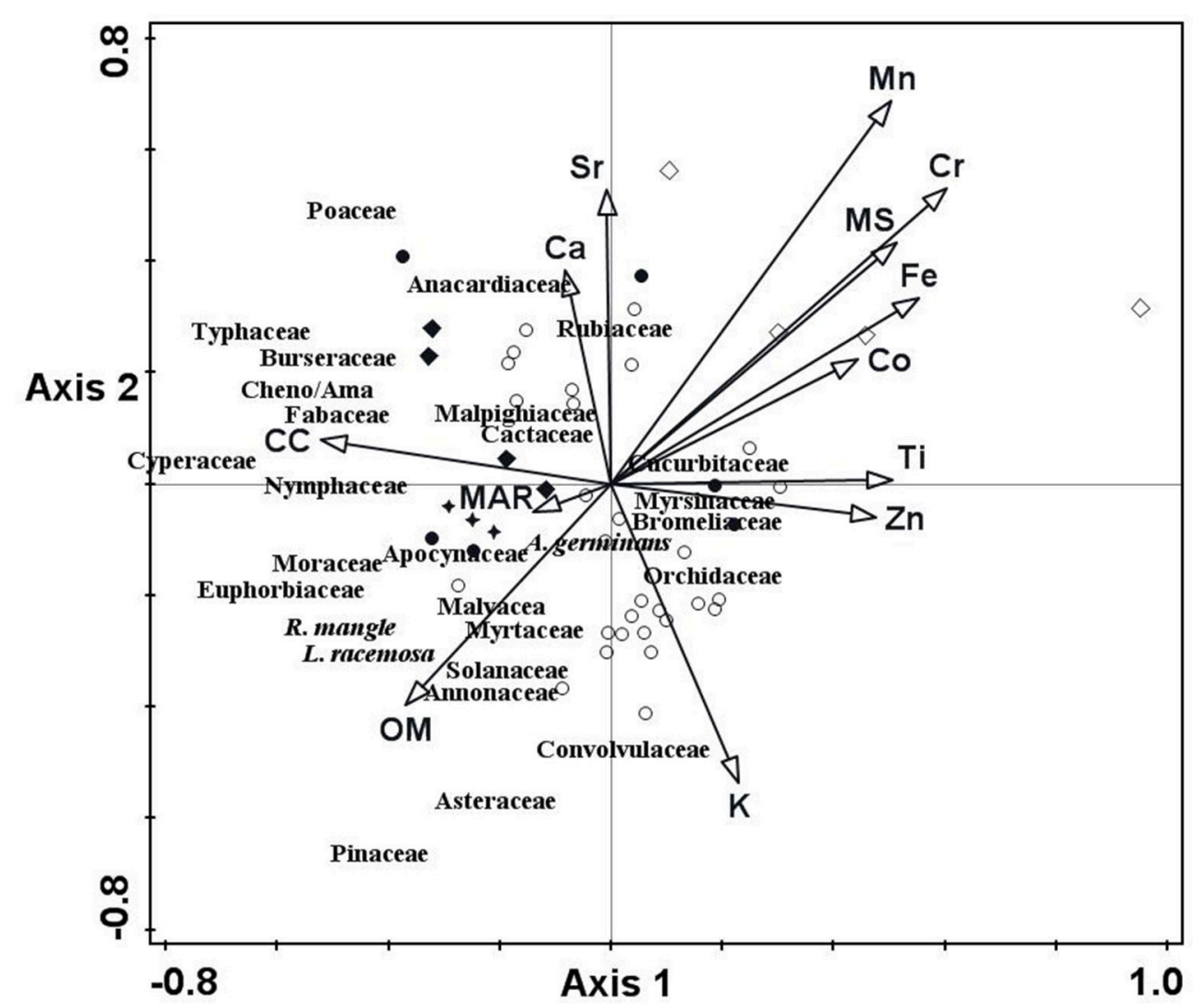

FIGURE 7 | Redundancy analysis triplot showing the relationship between pollen taxa composition with chemical element composition, Organic matter (OM), Carbonate Content (CC), Magnetic susceptibility (MS), and Mass Accumulation Rate (MAR). The different symbols represent ordination scores. They represent ages in calibrated years AD. Ages in black open circles correspond with the Little Ice Age; in black circles to ages previous to the MCA; in open black diamonds to the Medieval Climate Anomaly; in filled black diamonds to the Spanish Occupation and in black stars to the Manzanillo port opening and the tsunami of 1932.

are commonly found in coastal (Torrescano-Valle and Islebe, 2006; Joo-Chang et al., 2015) and mountain (Sosa-Nájera, 2013) lacustrine sediments; they are associated with brackish water and/or eutrophication. In particular, the species of Typha in the Cuyutlán Lagoon is Typha domingensis, a widespread and dominant plant in many aquatic systems. It also grows in industrial wastewater lakes, as the plant is resistant to pollution (Abdel-Ghani et al., 2009b) and is considered as a native "invasive" plant in swampy habitats (Horn and Kennedy (2006).

\section{The Timing of Mangrove Responses to Climatic Change}

Different episodes of climate change, human activity and extreme events were detected in the sequence retrieved in the Cuyutlán Lagoon as a local example from the Pacific west-central Mexico. Similarly, changes in climate and ecological dynamics have been reported from other mangrove-dominated coastal regions in Mexico (Gutiérrez-Ayala et al., 2012; Bocanegra Ramírez, 2014) and worldwide (Gilman et al., 2008; Monacci et al., 2011). These studies have shown that the abundance of mangroves has changed along with climate over time in response to climatic variations such as the LIA, MCA, and long-term variability in ENSO. In this research we used a multi-proxy approach together with multivariate numerical techniques to separate the samples corresponding to periods dominated by human activity from those marked by natural processes of climate change and extreme events.

\section{Medieval Climate Anomaly}

In the Cuyutlan Lagoon area the MCA was represented by zone $\mathrm{Z}-2$, which spanned the interval $\sim A D$ 712-1168. Zone Z-2 was an anomalous layer that was sedimentologically, geochemically, and palynologically complex. The inorganic nature of the sediment, the extremely high MS, and the enrichment in both $\mathrm{Sr}$ and a litany of terrigenous elements all suggest that this zone represents an event deposit, or multiple event deposits, of either storm or tsunami origin (McCloskey et al., 2015). The fact that pollen was present at the bottom of this inorganic layer, where OM was lowest and MS was highest, but absent in the top suggests that multiple events might have been represented (Liu et al., 2011). The occurrence of multiple peaks and troughs in the $\mathrm{OM}$ and elemental curves lends support to the interpretation of 
multiple events separated by intervals of temporary recovery. The enrichment of both marine ( $\mathrm{Sr}$ ) and terrigenous ( $\mathrm{Ti}, \mathrm{Fe}$ ) elements was also consistent with the scenario of marine incursion events (e.g., storm surge or tsunami run-up) accompanied by slope erosion due to heavy precipitation or tsunami return flow.

The MCA has been globally characterized by warm conditions regarding temperature (Mann et al., 2009), nonetheless there are divergent evidences in terms of precipitation. For some regions it was a dry period (Chen et al., 2015), for others it was characterized by humid conditions (Sosa-Nájera, 2013), though in general it is an incompletely understood episode of Late Holocene climatic change (Graham et al., 2011).

In any case, the overall character of zone Z-2 suggests that the MCA in the Cuyutlan Lagoon region was an environmentally highly perturbed period marked by the occurrence of multiple extreme events, which were more likely to be hurricanes than tsunamis based on their frequency of occurrence (several events over an interval of several centuries). The pollen data suggest that the abundance of $R$. mangle and tropical forest trees (Fabaceae, Euphorbiaceae, Moraceae) was high during the early phase of this period, but declined at the end. These palynological changes were consistent with the ecological impacts of hurricanes in tropical coastal areas (Kovacs et al., 2001; Alongi, 2008; Urquhart, 2009; Yao et al., 2015).

\section{Little Ice Age}

Most of the samples in our sequence covered the LIA $(\sim \mathrm{AD}$ 1350-1850) involving the upper half of zone Z-3 ( A.D 1381$1537)$, zone Z-4 ( $\sim \mathrm{AD} 1537-1739)$, and zone $\mathrm{Z}-5$ ( $\sim \mathrm{AD}$ 1739-1837). The central character of the LIA resided in cold temperatures and reduced precipitation (Hodell et al., 2005). During the early part of the LIA ( AD 1381-1537) mangrove species were infrequent, coupled with high percentages of Cheno/Ama, Cyperaceae and Poaceae. A possible explanation of the mangrove response in zone Z-3 could be a slow recovery phase after the extreme events of the MCA. The upper half of zone Z3 saw a distinct increase in the CC of the sediment, culminating in a broad peak in CC at the top of this zone. This may suggest greater marine influence resulting from more active tidal exchanges between the estuarine site and the sea (Yao et al., 2015). Cheno/Ama reached maximum frequencies possibly indicating an expansion of halophytic plant communities due to increased salinity of the water and soils in wetlands near the site. The two high peaks in CHAR could reflect either a dry environment at the site that promoted fire occurrence as vegetation experienced water stress triggering burning (RománCuesta et al., 2003), or with the use of fire in agriculture as most of the prehispanic civilizations in Mexico had already transformed land into fallows or open grasslands through clearing and burning (slash-and-burn) (Denevan, 1992; Lentz, 2000; Williams, 2003). Coincidentally after the fire event, palynological richness increased showing the highest values for the sequence. A conceivable reason is colonization of pioneer species, after the fire event, increasing plant biodiversity at certain tipping points (Liu et al., 2008).

The abundances of the terrigenous chemical elements were uniformly low during this interval representing the LIA. Ca and
Sr were also low in the upper half of the zone, although they exhibited pronounced peaks near the boundary between zone Z3 and zone $\mathrm{Z} 4$. The curves for these two marine-indicator elements seemed to covary with each other, and their peaks also seemed to correspond partly with a broader peak in CC. CC values were relatively high, especially in the lower part of this interval. The geochemical data are consistent with the scenario of a drier and more tranquil environment during the LIA with lowered storm activity and reduced soil erosion from the drainage basin (Rodríguez-Ramírez et al., 2015).

\section{The Timing of Mangrove Responses to Human Activity}

Different studies have attempted to explain the responses of Mexican mangrove forests to climate change, but those related to human activity are mainly located in the Yucatan Peninsula (Islebe and Sánchez, 2002; Torrescano-Valle and Islebe, 2006, 2012, 2015). This situation arose because the Maya civilization, developed in this Peninsula, had an important social, economic and cultural contribution to Mexican history. By contrast, western Mexico has received less attention compared to Mesoamerica despite the fact that from ancient times complex regional political systems had already been in place. In fact, various principal crops harvested in Mesoamerica were also domesticated in western Mexico and, in terms of religion, there are similarities in divinities between the two regions (Pollard, 1997; Beekman, 2010). On the other hand, the Pacific west central Mexico is a region susceptible to extreme events such as tsunamis (Bianchette et al.., in press). A collection of palaeoenvironmental studies (Figueroa-Rangel et al., 2008, 2010, 2012, 2016; Metcalfe et al., 2010; Sosa-Nájera et al., 2010; SosaNájera, 2013; Rodríguez-Ramírez et al., 2015; Valle Martínez, 2015; del Castillo-Batista et al., 2016) had reported the occurrence of crucial global events of climate change, such as the LIA and the MCA, in west central Mexico. This particular myriad of climate and human events occurring together makes it difficult to discern the exact impact and timing of human activity on vegetation. The main obstacle, however, continues to be the notion that humans disrupt the natural ecological conditions and processes that scientists try to understand (McDonnell and MacGregorFors, 2016). Therefore, we unceasingly look for the negative effects of human activities on vegetation when often humans have vastly contributed to its conservation.

But decisively with the current age-depth model and dating resolution, it is difficult to infer these important events in human history. However, it is of significance to mention the following events as inferred from this study:

\section{Spanish Occupation of Colima}

The middle part of the LIA ( AD 1537-1739; zone Z-4) overlapped with ages $\sim$ AD 1524-1561 of the Spanish Occupation of Colima, was clearly separated as a group in the NMDS ordinations. This situation is a clear example of a period where human activity and natural processes combined to exert a mixture of effects on the vegetation that are difficult to disentangle. Unfortunately with the current age-depth model and 
dating resolution, it is difficult to infer this important event in human history.

The original testimony of the occupation of Colima, as presented in the Fourth Letter of Cortés (October 15, 1524), described part of this region as belonging to the Tarascan king and during the conquest many people from Colima were killed by the Tarascans while the Spanish lost not a single person (Sauer, 1948). The Cuyutlán Lagoon was mentioned in Sauer's essay as a "boundary of encomiendas" in which the main tributes were fish and salt places; an encomienda was a means of giving to a Spaniard a restricted set of property rights over Indian labor (Yeager, 1995). Thus, we would expect a higher pressure over vegetation for this time due to increased human activity. However, in "Suma de Visitas de Pueblos" Lebron reported a decline in population from 1551 to 1554 ; a widespread episode in Mexico (Borah and Cook, 1962).

On the other hand, the phenomenon of El Niño Southern Oscillation (ENSO) was active during 1530-1560 (Sosa-Nájera, 2013), probably bringing more humidity and precipitation to the Pacific. This could have caused an increase in $R$. mangle to our site, as it has been reported in the Yucatán Peninsula (Islebe and Sánchez, 2002).

Finally, CC, $\mathrm{Ca}$, and $\mathrm{Sr}$ reached maximum values around $\mathrm{AD}$ 1545-1552. It is possible that these peaks in carbonates and marine indicators registered a hurricane or tsunami event, which led to an intrusion of marine waters and materials and further increased the salinity at the site. This marine intrusion event probably also caused new areas of mudflats and sand fans to form, creating new habitats for wetland plants to colonize, as indicated by the remarkable increase in the pollen abundance of $R$. mangle and Typhaceae. This can be interpreted as a recovery / resilience response or improved environmental conditions resulting from this particular event that promoted the development $R$. mangle (Dodd and Afzal Rafii, 2002; Alongi, 2008). On the other hand, increase in Typhaceae has been associated with low water level in lacustrine ecosystems, eutrophication and polluted, brackish water (Sosa-Nájera, 2013; Torres-Rodríguez, 2015). Typhaceae is also considered to be tolerant of high salinity, high temperature and disturbance. Its highest abundance was also coincident with a decrease in Fe and MS, possibly suggesting reduced soil erosion. Nevertheless, it has also been shown that Typha domingensis can remove aluminum, iron, zinc, and lead ions from soil and store these chemicals in their leaves, thus resulting in their depletion in the sediment (Abdel-Ghani et al., 2009a).

\section{The Manzanillo Port Opening and the Tsunami Earthquake of 1932}

Also included in the LIA period, the following part of the sequence ( $\sim \mathrm{AD}$ 1739-1837; zone Z-5) corresponded with episodes related to human activities in the Cuyutlán Lagoon; the most important were the artificial connections with the sea or the river, to improve productivity, sanitary conditions and for transport (Mellink and Riojas-López, 2007). AD 1824 marks the official opening of the Manzanillo Port (Patiño-Barragán et al., 2009). In 1889 a railroad was crossing the lagoon perpendicular to the sand barrier, and by 1932 the first artificial opening to the sea was constructed (Chavez Comparan, 1986).

Concerning the LIA, around $\mathrm{AD}$ 1708-1739, R. mangle showed a distinct decrease in abundance. This could be a regional reflection of a drought and low precipitation recorded in several parts of Mexico, including the Yucatan Peninsula and Central Mexico (Acuña-Soto et al., 2002; Mendoza et al., 2005).

Regarding natural events the great earthquake of 1932 was one of the largest to strike Mexico since the dawn of instrumental seismology (Okal and Borrero, 2011). Historical records showed the damage of the entire town of Cuyutlán by the arrival of the tsunami triggered by this earthquake (Corona and RamírezHerrera, 2012). The dramatic peak in CC at the top of the core (zone Z-6) probably reflects the marine intrusion event caused by the 1932 tsunami. A prominent peak was also presented in the marine indicators $\mathrm{Ca}$ and $\mathrm{Sr}$, accompanied by abrupt drops in MS and the terrigenous elements $\mathrm{Fe}, \mathrm{Mn}, \mathrm{Ti}$ and Cr. It is possible that the tsunami led to an intrusion of marine waters and materials and further increased the salinity at the site. This marine intrusion event possibly also caused new areas of mudflats and sand fans to form, creating new habitats for wetland plants to colonize, resulting in the increase of Cheno/Ama, Cyperaceae, and R. mangle at the top. After $\mathrm{AD}$ 1762, mangrove populations may also have increased as a response to a wetter period that brought more freshwater and moisture to the coast and to the inland area, including the increased frequency of hurricanes (Islebe and Sánchez, 2002; MEA, 2005).

\section{CONCLUSION}

The present research is a local-scale case where the interplay of human activity, climate change, and disturbance events composes the environmental history of mangrove vegetation during the late Holocene in the Pacific coast of west-central Mexico. Different episodes of vegetation change, allied with alterations in the geochemistry of the Cuyutlán Lagoon, reflect the complex interactions of climate change, human activity and the occurrence of extreme events. We found an assorted signature of anthropogenic and natural processes depending on the paleoecological proxies used. The individual effects of various processes are difficult to be deciphered from the paleoecological record, although the use of numerical techniques has helped to distinguish their resultant paleoenvironmental signatures during periods of time when different natural or anthropogenic processes predominated.

The main challenge, however, was the lack of a finer time resolution over the last 500 years when human activity in this region (indigenous agriculture and Spanish Occupation) was extensive, particularly during the last century when major infrastructural construction (Manzanillo Port Opening and railroad constructions) in the lagoon was expected to have significantly affected the mangrove ecosystem. Future studies should entail higher-resolution pollen analysis coupled with the use of both ${ }^{210} \mathrm{~Pb}$ and ${ }^{14} \mathrm{C}$ dating to separate the effect of climate change, extreme events (tsunamis and hurricanes), 
and human activity during the historical period to establish the modern analogs needed for more accurately deciphering the paleoenvironmental conditions of the Little Ice Age and the Medieval Climate Anomaly.

\section{AUTHOR CONTRIBUTIONS}

BF: Substantial contributions to the conception or design of the work, analysis, and interpretation of data; Drafting the work and revising it critically for important intellectual content; Final approval of the version to be published; Agreement to be accountable for all aspects of the work in ensuring that questions related to the accuracy or integrity of any part of the work are appropriately investigated and resolved. AV: Contributions to the conception or design of the work, data acquisition, analysis, and interpretation; Revising the work it critically; Final approval of the version; Agreement to be accountable for all aspects of the work. MO: Data acquisition and interpretation of data; Drafting the work and revising it critically for important intellectual content; Final approval of the version to be published; Agreement to be accountable for all aspects of the work; KL: Interpretation

\section{REFERENCES}

Abdel-Ghani, N. T., Hegazy, A. K., and El-Chaghaby, G. A. (2009a). Typha domingensis leaf powder for decontamination of aluminium, iron, zinc and lead: biosorption kinetics and equilibrium modeling. Int. J. Environ. Sci. Tec. 6, 243-248. doi: 10.1007/BF03327628

Abdel-Ghani, N. T., Hegazy, A. K., El-Chaghaby, G. A., and Lima, E. C. (2009b). Factorial experimental design for biosorption of iron and zinc using Typha domingensis phytomass. Desalination 249, 343-347. doi: 10.1016/j.desal.2009.02.065

Acuña-Soto, R., Sthahle, D. W., Cleaveland, M. K., and Therrell, M. D. (2002). Megadrought and megadeath in 16th century Mexico. Emerging Infect. Dis. 8, 360-362. doi: 10.3201/eid0804.010175

Alongi, D. M. (2008). Mangrove forests: resilience, protection from tsunamis, and responses to global climate change. Estuar. Coast. Shelf Sci. 76, 1-13. doi: 10.1016/j.ecss.2007.08.024

Beekman, C. S. (2010). Recent research in western Mexican archaeology. J. Archaeol. Res. 18, 41-109. doi: 10.1007/s10814-009-9034-x

Bennett, K. D. (1996). Determination of the number of zones in biostratigraphical sequence. New Phytol. 1, 155-170. doi: 10.1111/j.1469-8137.1996.tb04521.x

Bennett, K. D. (2009). PSIMPOLL 4.27 and PSCOMB 1.03 C Programs for Plotting Pollen Diagrams and Analysing Pollen Data. 4.27 Edn. Available online at: http://chrono.qub.ac.uk (Uppsala Universitet).

Bennett, K. D., and Willis, K. J. (2001). "Pollen," in Tracking Environmental Change Using Lake Sediments. Volume 3: Terrestrial, Algal and Siliceous Indicators, eds J. P. Smol and H. J. B. Birks (Dordrecht : Kluwer Academic Publishers), 5-32.

Bianchette, T., McCloskey, T. A., and Liu, K. B. (in press). A 7000-year History of Coastal Environmental Changes from Mexico's Pacific Coast: a Multi Proxy Record from Laguna. Mitla: The Holocene.

Birks, H. J. B., and Line, J. M. (1992). The use of rarefaction analysis for estimating palynological richness from Quaternary pollen-analytical data. Holocene 2, 1-10. doi: $10.1177 / 095968369200200101$

Blaauw, M. (2010). Methods and code for classical age-modeling of radiocarbon sequences. Quat. Geochronol. 5, 512-518. doi: 10.1016/j.quageo.2010.01.002

Bocanegra Ramírez, D. M. (2014). Efectos del Cambio Climático y las variaCiones del Nivel del Mar Sobre la Vegetación Costera de Chiapas, México Durante el Holoceno Medio y Tardío. Maestría en Geociencias y Planificación del Territorio, Universidad Michoacana de San Nicolás de Hidalgo, Morelia.

Borah, W., and Cook, S. F. (1962). La despoblación del México central en el siglo XVI. Hist. Mex. 12, 1-12. of data Drafting the work and revising it critically Final approval of the version Agreement to be accountable for all aspects of the work.

\section{FUNDING}

This research was supported by Conacyt (Mexican National Council for Science and Technology) through a Master Scholarship to the second author. The University of Guadalajara and Louisiana State University (through a grant \#SGP-CRA-2050 from the Inter-American Institute for Global Change Research, IAI) provided funds for the laboratory work.

\section{ACKNOWLEDGMENTS}

We are greatly indebted to people from El Tortugario-Centro Ecologico de Cuyutlán, particularly to Dr. Maricruz Rivera for field and logistic support; we also thank José Adalberto Arias Menaut and José Guadalupe Morales Arias for their assistance in fieldwork and to Terrence McCloskey, and Thomas Bianchette for their assistance in the laboratory work.

Calderón Aragón, G. (2001). Construcción y Reconstrucción del Desastre. México: Plaza Valdés, S.A. de C.V.

Carrillo-Bastos, A., Islebe, G. A., and Torrescano-Valle, N. (2013). 3800 Years of quantitative precipitation reconstruction from the Northwest Yucatan Peninsula. PLoS ONE 8:e84333. doi: 10.1371/journal.pone.0084333

Chavez Comparan, J. C. (1986). Considerations for Development of a Coastal Zone Management Program in the State of Colima, Mexico. MSc., Oregon State University.

Chen, J., Chen, F., Feng, S., Huang, W., Liu, J., and Zhou, A. (2015). Hydroclimatic changes in China and surroundings during the Medieval Climate Anomaly and Little Ice Age: spatial patterns and possible mechanisms. Quat. Sci. Rev. 107, 98-111. doi: 10.1016/j.quascirev.2014.10.012

Clark, J. S. (1988). Particle motion and the theory of charcoal analysis: source area, transport, deposition, and sampling. Quat. Res. 30, 67-80. doi: 10.1016/00335894(88)90088-9

CONABIO (2009). Los Manglares de México. México: Comisión Nacional para el Conocimiento y Uso de la Biodiversidad.

Corona, N., and Ramírez-Herrera, M. T. (2012). Mapping and historical reconstruction of the great Mexican 22 June 1932 tsunami. Nat. Hazards Earth Syst. Sci. 12, 1337-1352. doi: 10.5194/nhess-12-1337-2012

Dean, W. E. (1974). Determination of carbonate and organic matter in calcareous sediments and sedimentary rocks by loss on ignition. J. Sediment. Petrol. 44, $242-248$.

del Castillo-Batista, A. P., Figueroa-Rangel, B. L., Lozano-García, S., OlveraVargas, M., and Cuevas-Guzmán, R. (2016). Historia florística y ambiental del bosque mesófilo de montaña en el centro-occidente de México durante la pequeña edad de hielo. Rev. Mex. Biodivers. 87, 216-229. doi: 10.1016/j.rmb.2016.01.021

Denevan, W. M. (1992). The pristine myth: the landscape of the Americas in 1492 Ann. Assoc. Am. Geogr. 82, 369-385. doi: 10.1111/j.1467-8306.1992.tb01965.x

Dodd, R., and Afzal Rafii, Z. (2002). Evolutionary genetics of mangroves: continental drift to recent climate change. Trees 16, 80-86. doi: 10.1007/s00468001-0142-6

Figueroa-Rangel, B. L., Olvera-Vargas, M., Vázquez-López, J. M., Willis, K. J., and Lozano-García, S. (2016). Modern and fossil pollen assemblages reveal forest taxonomic changes in the Mexican subtropics during the last 1300 years. Rev. Palaeobot. Palynol. 231, 1-13. doi: 10.1016/j.revpalbo.2016.04.007

Figueroa-Rangel, B. L., Willis, K. J., and Olvera-Vargas, M. (2008). 4200 years of pine-dominated upland forest dynamics in west-central Mexico: human or natural legacy? Ecology 89, 1893-1907. doi: 10.1890/07-0830.1 
Figueroa-Rangel, B. L., Willis, K. J., and Olvera-Vargas, M. (2010). Cloud forest dynamics in the Mexican neotropics during the last 1300 years. Glob. Chang. Biol. 16, 1689-1704. doi: 10.1111/j.1365-2486.2009.02024.x

Figueroa-Rangel, B. L., Willis, K. J., and Olvera-Vargas, M. (2012). Late-holocene successional dynamics in a transitional forest of west-central Mexico. Holocene 22, 11. doi: 10.1177/0959683611414929

Friess, D. A., and Webb, E. L. (2014). Variability in mangrove change estimates and implications for the assessment of ecosystem service provision. Glob. Ecol. Biogeogr. 23, 715-725. doi: 10.1111/geb.12140

García, E. (1987). Modificaciones al Sistema de Clasificación Climática de Köppen. México: SIGSA.

Gilman, E. L., Ellison, J., Duke, N. C., and Field, C. (2008). Threats to mangroves from climate change and adaptation options: a review. Aquat. Bot. 89, 237-250. doi: 10.1016/j.aquabot.2007.12.009

Graham, N. E., Ammann, C. M., Fleitmann, D., Cobb, K. M., and Luterbacher, J. (2011). Support for global climate reorganization during the "Medieval Climate Anomaly." Clim. Dyn. 37, 1217-1245. doi: 10.1007/s00382-010-0914-z

Grove, J. M. (2001). The initiation of the "Little Ice Age" in regions around the North Atlantic. Clim. Change 48, 53-82. doi: 10.1023/A:10056628 22136

Gutiérrez-Ayala, L., Torrescano-Valle, N., and Islebe, G. A. (2012). Reconstrucción paleoambiental del Holoceno tardío de la reserva Los Petenes, Península de Yucatán, México. Revista Mexicana de Ciencias Geológicas 29, 749-763.

Hodell, D. A., Brenner, M., Curtis, J. H., Medina-Gonzalez, R., Chan Can, E. I., and Albornaz-Pat, A. (2005). Climate change on the Yucatan Peninsula during the Little Ice Age. Quat. Res. 63, 109-121. doi: 10.1016/j.yqres.2004. 11.004

Horn, S. P., and Kennedy, L. M. (2006). Pollen evidence of the prehistoric presence of cattail (Typha:Typhaceae) in Palo Verde National Park, Costa Rica. Brenesia $66,85-87$.

Hutchison, J., Manica, A. R. S., Balmford, A., and Spalding, M. (2014). Predicting global patterns in mangrove forest biomass. Conserv. Lett. 7, 233-240. doi: $10.1111 /$ conl.12060

INEGI (2009). Prontuario de Información Geográfica Municipal de Los Estados Unidos Mexicanos. Armería, Colima. Clave Geoestadística 06001. Mexico: INEGI.

Islebe, G. A., and Sánchez, O. (2002). History of Late Holocene vegetation at Quintana Roo, Caribbean coast of Mexico. Plant Ecol. 160, 187-192. doi: 10.1023/A:1015865932012

Joo-Chang, J. C., Islebe, G. A., and Torrescano-Valle, N. (2015). Mangrove history during middle- and late-Holocene in Pacific south-eastern Mexico. Holocene 25, 651-662. doi: 10.1177/0959683614566217

Kovacs, J., Blanco-Correa, M., and Flores-Verdugo, F. (2001). A logistic regression model of hurricane impacts in a Mangrove Forest of the Mexican Pacific. J. Coast. Res. 17, 8.

Krauss, K. W., McKee, K. L., Lovelock, C. E., Cahoon, D. R., Saintilan, N., Reef, R., et al. (2014). How mangrove forests adjust to rising sea level. New Phytol. 202, 19-34. doi: 10.1111/nph.12605

Lentz, D. L. (2000). “Anthropocentric food webs in the Precolumbian Americas," in Imperfect Balance: Landscape Transformations in the Precolumbian Americas, ed D. L. Lentz (New York, NY: Columbia University Press), 89-119.

Liu, K. B., and Fearn, M. L. (2000a). "Holocene history of catastrophic hurricane landfalls along the Gulf of Mexico Coast reconstructed from coastal lake and marsh sediments," in Current Stresses and Potential Vulnerabilities: Implications of Global Change for the Gulf Coast Region of the United States, eds Z. H. Ning and K. K. Abdollahi (Baton Rouge, LA: Franklin Press Inc.), 10.

Liu, K. B., and Fearn, M. L. (2000b). Reconstruction of prehistoric landfall frequencies of catastrophic hurricanes in Northwestern Florida from lake sediments records. Quat. Res. 54, 8. doi: 10.1006/qres.2000.2166

Liu, K. B., Li, C. Y., Bianchette, T. A., McCloskey, T. A., Yao, Q., and Weeks, E. (2011). Storm deposition in a coastal backbarrier lake in Louisiana caused by Hurricanes Gustav and Ike. J. Coast. Res. SI 64, 1866-1870.

Liu, K. B., Lu, H. Y., and Shen, C. M. (2008). A 1200-year proxy record of hurricanes and fires from the Gulf of Mexico coast: testing the hypothesis of hurricane-fire interactions. Quat. Res. 69, 29-41. doi: 10.1016/ j.yqres.2007.10.011

López-Portillo, J., and Ezcurra, E. (2002). Los manglares de méxico: una revisión. Madera y Bosques 8, 26.
Mann, M. E., Zhang, Z., Rutherford, S., Bradley, R. S., Hughes, M. K., Shindell, D., et al. (2009). Global signatures and dynamical origins of the Little Ice Age and medieval climate anomaly. Science 326, 1256-1260. doi: $10.1126 /$ science. 1177303

Mayewski, P. A., Rohling, E. E., Stager, J. C., Karlén, W., Maasch, K. A., Meeker, L. D., et al. (2004). Holocene climate variability. Quat. Res. 62, 243-255. doi: 10.1016/j.yqres.2004.07.001

McCloskey, T. A., Bianchette, T. A., and Liu, K. B. (2015). Geological and sedimentological evidence of a large tsunami occurring $\sim 1100$ year BP from a small coastal lake along the Bay of La Paz in Baja California Sur, Mexico. J. Mar. Sci. Eng. 3, 1544-1567. doi: 10.3390/jmse3041544

McCloskey, T. A., and Liu, K. B. (2012). A sedimentary-based history of hurricane strikes on the southern Caribbean coast of Nicaragua. Quat. Res. 78, 454-464. doi: 10.1016/j.yqres.2012.07.003

McDonnell, M. J., and MacGregor-Fors, I. (2016). The ecological future of cities. Science 352, 936-938. doi: 10.1126/science.aaf3630

McLeod, E., and Salm, R. V. (2006). Managing Mangroves for Resilience to Climate Change. IUCN Resilience Science Group Working Paper Series - No 2. Gland.

MEA (2005). Ecosystems and Human Well-being: Synthesis. Washington, DC: Island Press.

Mellink, E., and Riojas-López, M. (2007). Modificaciones estructurales artificiales de Laguna Cuyutlán, Colima, México. Revista Geográfica 142, 131-142.

Mendoza, B., Jáuregui, E., Sandoval-Díaz, R., García-Acosta, V., Velasco, V., and Cordero, G. (2005). Historical droughts in Central México and their relation with El Niño. J. Appl. Meteorol. 14, 709-716. doi: 10.1175/JAM2210.1

Metcalfe, S. E., Jones, M. D., Davies, S. J., Noren, A., and MacKenzie, A. (2010). Climate variability over the last two millennia in the North American Monsoon region, recorded in laminated lake sediments from Laguna de Juanacatlán, Mexico. Holocene 20, 1195-1206. doi: 10.1177/0959683610371994

Meyers, P. A., and Teranes, J. L. (2001). "Sediment organic matter," in Tracking Environmental Change Using Lake Sediments. Volume 2: Physical and Geochemical Methods, eds W. M. Last and J. P. Smol (Dordrecht: Kluwer Academic Publishers), 239-269.

Monacci, N. M., Meier-Grünhagen, U., Finney, B. P., Behling, H., and Wooller, M. J. (2011). Paleoecology of mangroves along the Sibun River, Belize. Quat. Res. 76, 220-228. doi: 10.1016/j.yqres.2011.06.001

Okal, E. A., and Borrero, J. C. (2011). The tsunami earthquake of 1932 June 22 in Manzanillo,Mexico: seismological study and tsunami simulations. Geophys. J. Int. 187, 1443-1459. doi: 10.1111/j.1365-246X.2011.05199.x

Padilla-Velarde, E., Cuevas-Guzmán, R., Ibarra-Manríquez, G., and MorenoGómez, S. (2006). Riqueza y biogeografía de la fl ora arbórea del estado de Colima, México. Rev. Mex. Biodivers. 77, 271-295. doi: 10.7550/rmb.5289

PAGES-2k-Consortium (2013). Continental-scale temperature variability during the past two millennia. Nat. Geosci. 6, 339-346. doi: 10.1038/nge 01797

Patiño-Barragán, M., Meyer-Willerer, A. O., Galicia Pérez, M. A., Lezama Cervantes, C., and Lara Chávez, B. (2009). Zona de mayor afectación en el puerto de manzanillo colima méxico, por eventos hidrometeorológicos intensos y su periodicidad. Boletín Técnico IMME 47, 47-60.

Pollard, H. P. (1997). Recent research in west Mexican archaeology. J. Archaeol. Res. 5, 345-384. doi: 10.1007/BF02229257

Reimer, P. J., Bard, E., Bayliss, A., Beck, J. W., Blackwell, P. G., Bronk Ramsey, C., et al. (2013). Intcal13 and Marine13 Radiocarbon age calibration curves, 0-50,000 years Cal BP. Radiocarbon 55, 1869-1887. doi: $10.2458 /$ azu_js_rc.55.16947

Rodríguez-Ramírez, A., Caballero, M., Roy, P., Ortega, B., Vázquez-Castro, G., and Lozano-García, S. (2015). Climatic variability and human impact during the last 2000 years in western Mesoamerica: evidence of late Classic (AD 600-900) and Little Ice Age drought events. Clim. Past 11, 1239-1248. doi: 10.5194/cp-11-1239-2015

Román-Cuesta, R. M., Gracia, M., and Retana, J. (2003). Environmental and human factors influencing fire trends in Enso and Non-Enso years in tropical Mexico. Ecol. Appl. 13, 1177-1192. doi: 10.1890/1051-0761(2003) 13[1177:EAHFIF]2.0.CO;2

Ruíz-Montero, A. P. (2009). Ficha Informativa de Los Humedales de Ramsar: Laguna de Cuyutlán vasos III y IV. México: Convención de Ramsar.

Sauer, C. (1948). Colima of the new Spain in the sixteen century. Ibero-Americana $29,1-57$. 
Sosa-Nájera, M. S. (2013). El Holoceno Tardío en el Occidente de México: el Registro Palinológico y Geoquímico del Lago Crater de Santa María del oro, Nayarit. Ph.D. Doctoral Thesis, Universidad Nacional Autónoma de México.

Sosa-Nájera, S., Lozano-García, S., Roy, P. D., and Caballero, M. (2010). Registro de sequías históricas en el occidente de México con base en el análisis elemental de sedimentos lacustres: El caso del lago de Santa María del Oro. Boletín de la Sociedad Geológica Mexicana 62, 437-451.

Téllez García, C. P. (2010). Caracterización Dasonómica del Bosque de Mangles en el Estero Palo Verde, Laguna de. Cuyutlán: Universidad de Chapingo.

ter Braak, C. J. F. (1986). Canonical correspondence analysis: a new eigenvector technique for multivariate direct gradient analysis. Ecology 67, 1167-1179. doi: $10.2307 / 1938672$

ter Braak, C. J. F., and Smilauer, P. (2012). CANOCO Reference Manual and User's Guide: Software for Ordination (version 5.0). Wageningen.

Thompson, R., and Oldfield, F. (1986). Environmental Magnetism. London: Allen and Unwin.

Torres, J., and Quintanilla-Montoya, A. L. (2014). Alteraciones antrópicas: historia de la Laguna de Cuyutlán, Colima. Investigación Ambiental. Ciencia y Politica Pública 6, 29-42.

Torres-Rodríguez, E. (2015). Historia Climática y Cambios en la Vegetación en la Cuenca de México durante el Último ciclo Glacial. Ph.D. Universidad Nacional Autonoma de Mexico.

Torrescano-Valle, N., and Islebe, G. A. (2006). Tropical forest and mangrove history from southeastern Mexico: a 5000 yr pollen record and implications for sea level rise. Veget Hist Archaeobot 15, 5. doi: 10.1007/s00334-005-0 007-9

Torrescano-Valle, N., and Islebe, G. A. (2012). Mangroves of Southeastern Mexico: palaeoecology and Conservation. Open Geogra. J. 5, 10. doi: $10.2174 / 1874923201205010006$

Torrescano-Valle, N., and Islebe, G. A. (2015). Holocene paleoecology, climate history and human influence in the southwestern Yucatan Peninsula. Rev. Palaeobot. Palynol. 217, 1-8. doi: 10.1016/j.revpalbo.2015. 03.003

UNEP (1994). Assessment and Monitoring of Climatic Change Impacts on Mangrove Ecosystems. Regional Seas Reports and Studies No. 154.

Urquhart, G. R. (2009). Paleoecological record of hurricane disturbance and forest regeneration in Nicaragua. Quat. Int. 195, 88-97. doi: 10.1016/j.quaint.2008.05.012
Valle Martínez, A. (2015). Historia Paleoecológica del Manglar de la Laguna de Cuyutlán en el Pacífico Mexicano y su Relación con Cambios Ambientales M.Sc., Universidad de Guadalajara.

Villanueva-Gutiérrez, R., Palacios-Chávez, R., and Ludlow-Wiechers, B. (1991). Flora Palinológica de la Reserva de la Biosfera de Sian Kảan, Quintana Roo. México: Centro de Investigaciones de Quintana Roo.

Wanner, H., Beer, J., Bütikofer, J., Crowley, T. J., Cubasch, U., Flückiger, J., et al. (2008). Mid- to Late Holocene climate change: an overview. Quat. Sci. Rev. 27, 1791-1828. doi: 10.1016/j.quascirev.2008. 06.013

Whitlock, C., and Larsen, C. (2001). "Charcoal as a fire proxy," in Tracking Environmental Change Using Lake Sediments. Volume 3: Terrestrial, Algal and Siliceous Indicators, eds J. P. Smol and H. J. B. Birks (Dordrecht: Kluwer Academic Publishers), 75-97.

Williams, M. (2003). Deforesting the Earth: from Prehistory to Global Crisis. Chicago, IL: The University of Chacago Press.

Woodruff, J. D., Kanamaru, K., Kundu, S., and Cook, T. L. (2015). Depositional evidence for the Kamikaze typhoons and links to changes in typhoon climatology. Geology 43, 91-94. doi: 10.1130/G36209.1

Yao, Q., Liu, K. B., Platt, W. J., and Rivera-Monroy, V. H. (2015). Palynological reconstruction of environmental changes in coastal wetlands of the Florida Everglades since the mid-Holocene. Quat. Res. 83, 449-458. doi: 10.1016/j.yqres.2015.03.005

Yeager, T. J. (1995). Encomienda or Slavery? The spanish crown's choice of labor organization in sixteenth century Spanish America. J. Econ. Hist. 55, 842-859. doi: $10.1017 /$ S0022050700042182

Conflict of Interest Statement: The authors declare that the research was conducted in the absence of any commercial or financial relationships that could be construed as a potential conflict of interest.

Copyright (๔ 2016 Figueroa-Rangel, Valle-Martínez, Olvera-Vargas and Liu. This is an open-access article distributed under the terms of the Creative Commons Attribution License (CC BY). The use, distribution or reproduction in other forums is permitted, provided the original author(s) or licensor are credited and that the original publication in this journal is cited, in accordance with accepted academic practice. No use, distribution or reproduction is permitted which does not comply with these terms. 